\title{
Fatty Acid Metabolism in the Perfused Rat Liver
}

\author{
By H. A. KREBS AND R. HEMS \\ Metabolic Research Laboratory, Nuffield Department of Clinical Medicine, \\ Radcliffe Infirmary, Oxford OX2 6HE, U.K.
}

(Received 8 May 1970)

\begin{abstract}
1. The formation of acetoacetate, $\beta$-hydroxybutyrate and glucose was measured in the isolated perfused rat liver after addition of fatty acids. 2 . The rates of ketonebody formation from ten fatty acids were approximately equal and independent of chain length (90-132 $\mu \mathrm{mol} / \mathrm{h}$ per $\mathrm{g}$ ), with the exception of pentanoate, which reacted at one-third of this rate. The [ $\beta$-hydroxybutyrate]/[acetoacetate] ratio in the perfusion medium was increased by long-chain fatty acids. 3. Glucose was formed from all odd-numbered fatty acids tested. 4. The rate of ketone-body formation in the livers of rats kept on a high-fat diet was up to $50 \%$ higher than in the livers of rats starved for $48 \mathrm{~h}$. In the livers of fat-fed rats almost all the $\mathrm{O}_{2}$ consumed was accounted for by the formation of ketone bodies. 5 . The ketone-body concentration in the blood of fat-fed rats rose to 4-5 mM and the [ $\beta$-hydroxybutyrate]/[acetoacetate] ratio rose to 11.5. 6. When the activity of the microsomal mixed-function oxidase system, which can bring about $\omega$-oxidation of fatty acids, was induced by treatment of the rat with phenobarbitone, there was no change in the ketone-body production from fatty acids, nor was there a production of glucose from even-numbered fatty acids. The latter would be expected if $\omega$-oxidation occurred. Thus $\omega$-oxidation did not play a significant role in the metabolism of fatty acids. 7. Arachidonate was almost quantitatively converted into ketone bodies and yielded no glucose, demonstrating that gluconeogenesis from polyunsaturated fatty acids with an even number of carbon atoms does not occur. 8. The rates of ketogenesis from unsaturated fatty acids (sorbate, undecylenate, crotonate, vinylacetate) were similar to those from the corresponding saturated fatty acids. 9. Addition of oleate together with shorter-chain fatty acids gave only a slightly higher rate of ketone-body formation than oleate alone. 10. Glucose, lactate, fructose, glycerol and other known antiketogenic substances strongly inhibited endogenous ketogenesis but had no effects on the rate of ketone-body formation in the presence of $2 \mathrm{~mm}$-oleate. Thus the concentrations of free fatty acids and of other oxidizable substances in the liver are key factors determining the rate of ketogenesis.
\end{abstract}

The isolated perfused rat liver offers the possibility of studying many quantitative aspects of liver metabolism with much greater accuracy than is practical in the whole organism or any other tissue preparations. The perfused organ has proved to be superior to slices, homogenates and other tissue preparations because much of the normal metabolic capacity as well as the control mechanisms are lost on disturbing the structure of the organ (Krebs, Wallace, Hems \& Freedland, 1969).

The present work continues previous experiments on the perfused rat liver (Krebs et al. 1969) and is concerned with a systematic investigation of the rates of ketone-body formation from fatty acids of various chain lengths, of the rate of glucose forma- tion from fatty acids with uneven numbers of carbon atoms, the question of the occurrence of $\omega$-oxidation, and of the effects of high-fat diets and other factors on the capacity of the liver to degrade fatty acids and to convert them into ketone bodies.

\section{MATERIALS AND METHODS}

The liver perfusions were carried out as described by Krebs et al. (1969). Substrates were added $38 \mathrm{~min}$ after the start of the perfusion and continued for a total of $130 \mathrm{~min}$. 'Zero' time was $40 \mathrm{~min}$ after the start. The fatty acids used were the purest commercially available. Oleic acid ('puriss') was obtained from Fluka A.G. Chemische Fabrik, Buchs, Switzerland, as a colourless fluid stated to be at least $99 \%$ pure. Yellow-coloured samples of oleic acid from other sources gave lower 
metabolic rates. Arachidonic acid was kindly supplied by $\mathrm{Dr}$ J. M. Osbond of Roche Products Ltd., Welwyn Garden City, Herts., U.K. It was obtained from the ethyl ester by mild alkaline hydrolysis. The ester had been prepared by the method of Osbond (1966). The preparation of long chain fatty acid stock solutions was as described by Krebs et al. (1969); it was not necessary to add bovine albumin to the stock solution when the chain length was below eight carbon atoms. Female albino rats of the Wistar strain, supplied by Scientific Products Farm, Ash Research Centre, Canterbury, Kent, U.K., weighing about $200 \mathrm{~g}$ were used.

Analytical methods were the same as previously described (Krebs et al. 1969) except that the Van Slyke apparatus instead of the Natelson apparatus was used for the determination of oxygen in the perfusion fluid. The oxygen determinations were carried out on $3 \mathrm{ml}$ samples. The term 'total ketone bodies' refers to the sum of $\beta$-hydroxybutyrate and acetoacetate. There was no evidence to indicate a significant formation of acetone under test conditions. When acetoacetate or $\beta$-hydroxybutyrate was added to the perfused liver the amount of 'total ketone bodies' recovered was always greater than the initial amount added.

High-fat diets consisted of either 90 parts of margarine and 10 parts of casein or 95 parts of margarine and 5 parts of casein, with a supplement of salts and vitamins.

To increase the activity of the hepatic microsomal oxidases, taken to be responsible for $\omega$-oxidation of fatty acids (see Das, Orrenius \& Ernster, 1968), phenobarbitone, dissolved in $0.5 \mathrm{ml}$ of $0.9 \% \mathrm{NaCl}$, was given to rats intraperitoneally on five consecutive days. The injections $(100 \mathrm{mg} / \mathrm{kg}$ body wt. per day) were given in the morning so that during the night the rats were active and taking in food (Remmer, 1959; Remmer, Greim, Schenkman \& Estabrook, 1967). On the fourth and fifth days the rats were starved to be used on the sixth day.

\section{RESULTS}

Rates of formation of ketone bodies and of glucose in the perfused rat liver in the presence of fatty acids. Table 1 expands information given previously, which covered four fatty acids with an even number of carbon atoms (Krebs et al. 1969). The rates of total ketone-body formation in the presence of optimal concentrations of ten fatty acids in the livers from starved rats were about the same and independent of the length of the carbon chain (between 90 and $132 \mu \mathrm{mol} / \mathrm{h}$ per $\mathrm{g}$ ), with the exception of $n$-valerate (pentanoate) which reacted at one-third of the rate of the other acids, and propionate, which is glucogenic and antiketogenic. The rates of total ketone-body production were fairly constant throughout the perfusion time of 90 min after addition of the substrate, but, as reported previously (Table 1 in Krebs et al. 1969), the $[\beta$-hydroxybutyrate]/[acetoacetate] ratio tended to decrease during the perfusion, the decrease being similar for all substrates. The ratio depended on the length of the carbon chain and on the rate of oxidation. Long-chain substrates gave
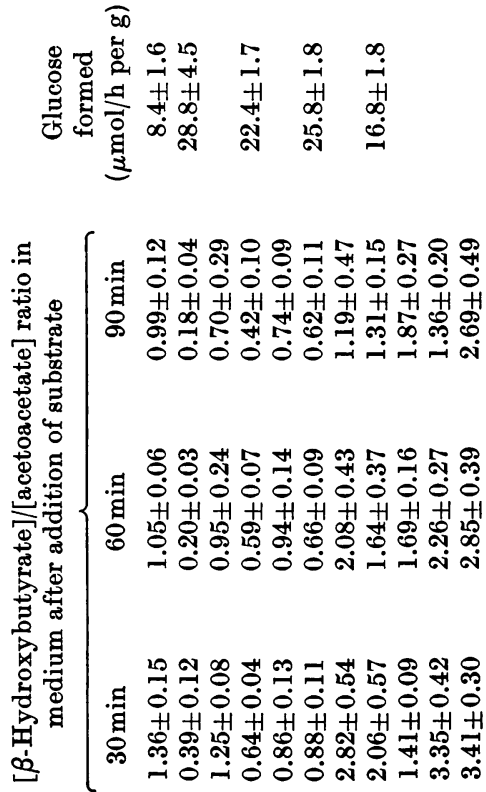

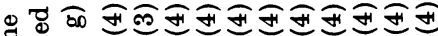

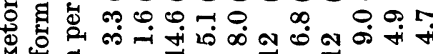
要 $\mathrm{H}+\mathrm{H} H \mathrm{H}+\mathrm{H}+\mathrm{H} H \mathrm{H}$

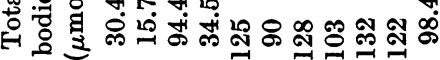

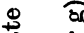

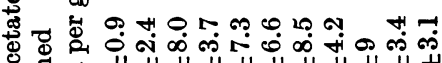

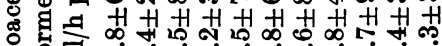

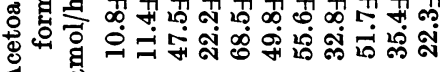
43
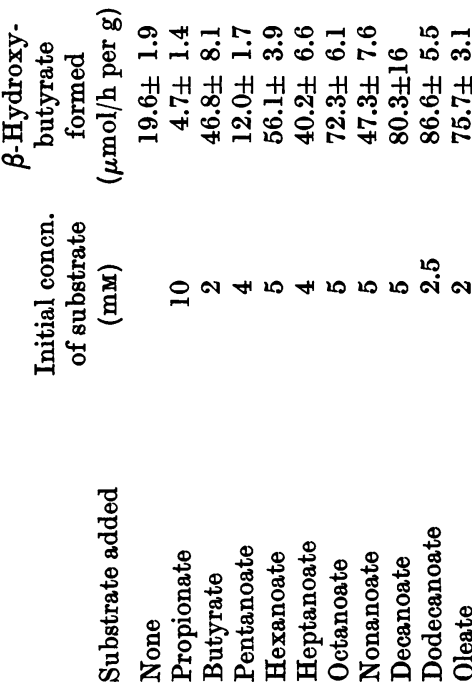
Table 2. Yield of glucose and ketone bodies on perfusing rat livers with fatty acids with an odd number of carbon atoms

Livers of starved $(48 \mathrm{~h})$ rats were perfused for $90 \mathrm{~min}$ after addition of the fatty acids. The experiments were those for which the initial rates were given in Table 1. The expected ratio of ketone bodies formed/glucose formed was calculated on the assumption that per molecule of fatty acid 0.5 molecule of glucose was formed and that the remaining carbon atoms formed ketone bodies.

Glucose formed after addition of substrate ( $\mu \mathrm{mol})$

Fatty acid added

Pentanoate

Heptanoate

Nonanoate

$$
242 \pm 22(4)
$$

$306 \pm 18.5(4)$

$267 \pm 134$ (2)
Ketone bodies formed after addition of substrate ( $\mu \mathrm{mol}$ )

$370 \pm 57(4)$

$888 \pm 165(4)$

$899 \pm 92(2)$
Ketone bodies formed

\begin{tabular}{|c|c|}
\hline \multicolumn{2}{|c|}{ Glucose formed } \\
\hline Found & Expected \\
\hline 1.5 & 1.0 \\
\hline 2.9 & 2.0 \\
\hline 3.35 & 3.0 \\
\hline
\end{tabular}

Table 3. Rates of formation of ketone bodies from fatty acids in the perfused liver of rats fed on a diet rich in fat

The general conditions were as described in Table 1 . The rats were kept for at least 8 days on a diet containing $90 \%$ margarine. The remainder was casein, vitamins and salts. The values are means \pm s.E.M. for four observations. The concentrations of fatty acids used were those which, as established in preliminary tests, give maximal rates.

\begin{tabular}{|c|c|c|c|c|c|}
\hline Substrate added & $\begin{array}{c}\text { Initial } \\
\text { concentration } \\
\text { of substrate } \\
(\mathrm{mM})\end{array}$ & $\begin{array}{c}\beta \text {-Hydroxy- } \\
\text { butyrate formed } \\
(\mu \mathrm{mol} / \mathrm{h} \text { per } \mathrm{g})\end{array}$ & $\begin{array}{c}\text { Acetoacetate } \\
\text { formed } \\
(\mu \mathrm{mol} / \mathrm{h} \text { per } \mathrm{g})\end{array}$ & $\begin{array}{l}\text { Total ketone } \\
\text { bodies formed } \\
(\mu \mathrm{mol} / \mathrm{h} \text { per } \mathrm{g})\end{array}$ & $\frac{[\beta \text {-Hydroxybutyrate }]}{[\text { Acetoacetate }]}$ \\
\hline None & & $9.09 \pm 0.76$ & $35.1 \pm 4.4$ & $44.3 \pm 3.8$ & 0.26 \\
\hline Hexanoate & 5 & $62.9 \pm 11.1$ & $79.3 \pm 7.9$ & $142 \pm 18.9$ & 0.79 \\
\hline Octanoate & $\mathbf{5}$ & $91.8 \pm 6.8$ & $53.4 \pm 3.9$ & $145 \pm 7.7$ & 1.72 \\
\hline Dodecanoate & 2.5 & $115 \pm 12.1$ & $43.7 \pm 11.9$ & $159 \pm 12.8$ & 2.63 \\
\hline Oleate & 2 & $113 \pm 28.6$ & $33.1 \pm 7.6$ & $146 \pm 7.6$ & 3.41 \\
\hline
\end{tabular}

high ratios, medium-length fatty acids raised the ratio above that of the unsupplemented control, but pentanoate, which was oxidized slowly, caused a decrease, and propionate also gave very low ratios. In general, fatty acids of approximately the same molecular weight and having either an even or odd number of carbon atoms gave about the same ratios. Glucose was formed, as expected, from all fatty acids with an odd number of carbon atoms tested. None of the fatty acids with an even number of carbon atoms gave significant increases of the glucose output over the controls without added substrate (not recorded in Table 1).

The total yield of glucose formed from the fatty acids with an odd number of carbon atoms was in each case less than expected on the basis of the formation of ketone bodies (Table 2). The deficit was small in the case of nonanoate where the yield of glucose was $89 \%$ of the theoretical yield. With pentanoate and heptanoate the yields were only 65 and $69 \%$ respectively. The fate of the three carbon atoms not recovered as glucose is uncertain. Glycogen synthesis was negligible under the test conditions.
Adaptation to high-fat diets. Experience of prolonged starvation indicates that the mammalian body can adapt its energy metabolism to the utilization of fat (Cahill, Owen \& Morgan, 1968). To test whether such adaptation occurs in liver, rats were given the diet containing $90 \%$ margarine and $10 \%$ casein. The animals were kept on this diet for 7-18 days. As shown in Table 3 the rates of ketone-body formation were substantially higher than in rats starved for $48 \mathrm{~h}$ (Table 1), although the fat-fed rats were not starved. After two or three days of under-eating and some weight loss they ate enough food to maintain their body weight after the initial loss. When oleate was added as substrate the increase in the rate of ketone-body formation was about $50 \%$. It was between 10 and $20 \%$ with the other fatty acids tested. The endogenous rate was increased by about $50 \%$. The [ $\beta$-hydroxybutyrate]/[acetoacetate] ratio tended to be higher with the long-chain fatty acids, but was much lower when no substrate had been added.

The comparison of the rate of ketone-body formation and oxygen consumption by the livers from rats on the high-fat diet (Tables 4 and 5) 


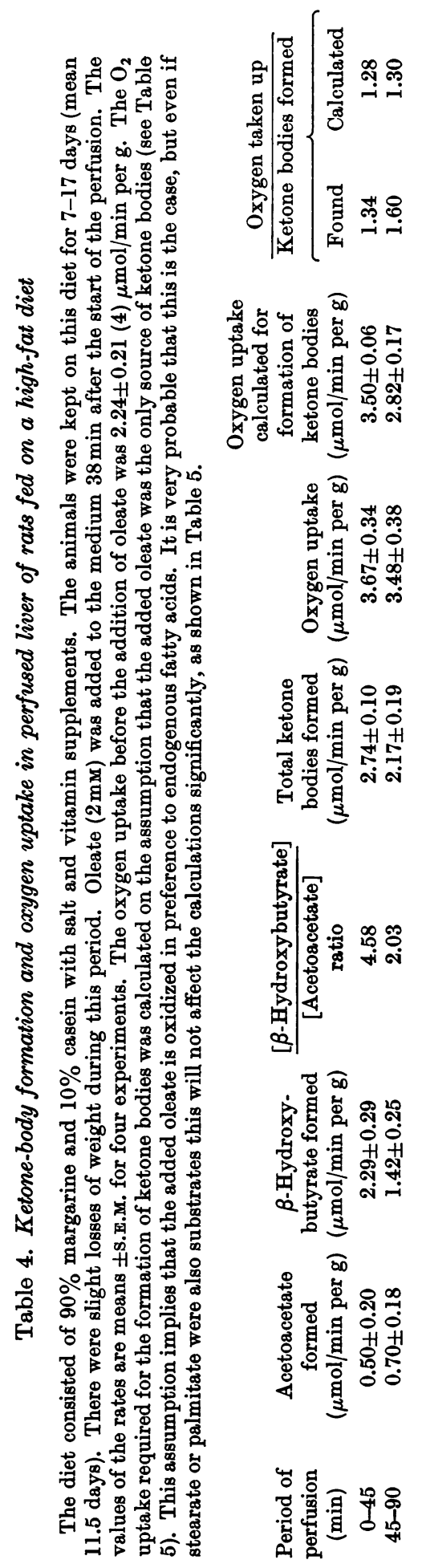

indicates that almost all the oxygen consumption was used in the formation of ketone bodies from the added oleate (95\% during the first $45 \mathrm{~min}$ and $81 \%$ during the second $45 \mathrm{~min}$ ). On the assumption that oleate was the only substrate oxidized, $75 \%$ of the added oleate had disappeared after $90 \mathrm{~min}$. As the rate of oxidation of oleate is concentration-dependent (see Krebs et al. 1969) the decrease in the ratio $\mathrm{O}_{2}$ used/ketone bodies formed was probably due to a decreased concentration of oleate. Thus when fatty acids are available in saturating concentrations, i.e. those giving maximal rates (as is likely in vivo in the liver of fat-fed rats), almost the whole of the respiration of livers from rats kept on a high-fat diet serves to supply the body with ketone bodies. The needs of the liver for ATP synthesis are presumably met by the energy released in the dehydrogenations involved in the formation of ketone bodies.

The rate of ketone-body formation in the livers of well-fed rats (see Krebs et al. 1969) in the presence of saturating concentrations of oleate was no more than one-quarter of the rates found with fat-fed livers.

There was a loss of body weight of approx. $35 \mathrm{~g}$ per rat of $240 \mathrm{~g}$ weight during the initial week on the high-fat diet, because of a decreased food intake (Table 6). After the first week the body weights remained fairly constant during the period of observation (18 days).

Blood ketone-body concentrations in fat-fed rats. When fat-fed rats were used for the perfusion experiments blood samples were taken for the determination of ketone bodies (Table 6). The total ketone-body concentration rose to between 4 and $5 \mathrm{mM}$ and the [ $\beta$-hydroxybutyrate]/[acetoacetate] ratio also increased, to a mean value of 7.2 after 7-12 days and 11.5 after 17-18 days. No definite trends were discernible between days 7 and 18 on the high-fat diet. Variations were considerable, as indicated by the values for the S.E.M. ; the variations were erratically distributed over the periods of observation.

Effect of diet on liver weight. The wet weight of the liver per $100 \mathrm{~g}$ body weight remained unchanged (Table 7). Starvation on the other hand caused a loss of fresh weight of $12.8 \%$ and of dry weight of $19.8 \%$ (Table 6). The greater loss of dry weight can be explained by the assumption that the loss concerned mainly storage materials, e.g. glycogen. The fresh-weight gain on the high-fat diet must have been mainly water since it was not accompanied by a parallel gain in dry weight.

Question of $\omega$-oxidation of fatty acids. The occurrence of $\omega$-oxidation of fatty acids was discovered by Verkade \& van der Lee (1934) (see also Verkade, van der Lee \& van Alphen, 1938); but experiments by Bernhard (1941) suggested that it is a minor 
Table 5. Calculated quantitative relations between $\mathrm{O}_{2}$ uptake and ketone-body formation from long-chain fatty acids

\begin{tabular}{|c|c|c|c|c|}
\hline \multirow[b]{2}{*}{ Fatty acid } & \multirow{2}{*}{\multicolumn{2}{|c|}{ Overall reaction }} & \multirow{2}{*}{$\frac{\mathrm{O}_{2} \text { used }}{\text { Acetoacetate formed }}$} & \multirow{2}{*}{$\frac{\mathrm{O}_{2} \text { used }}{\beta \text {-Hydroxybutyrate formed }}$} \\
\hline & & & & \\
\hline Oleate & $\mathrm{C}_{18} \mathrm{H}_{34} \mathrm{O}_{2}+7.5 \mathrm{O}_{2}$ & $\rightarrow 4.5$ acetoacetate & 1.66 & \\
\hline Oleate & $\mathrm{C}_{18} \mathrm{H}_{34} \mathrm{O}_{2}+5.25 \mathrm{O}_{2}$ & $\rightarrow 4.5 \beta$-hydroxybutyrate & & 1.17 \\
\hline Stearate & $\mathrm{C}_{18} \mathrm{H}_{36} \mathrm{O}_{2}+8 \mathrm{O}_{2}$ & $\rightarrow 4.5$ acetoacetate & 1.78 & \\
\hline Stearate & $\mathrm{C}_{18} \mathrm{H}_{36} \mathrm{O}_{2}+5.75 \mathrm{O}_{2}$ & $\rightarrow 4.5 \beta$-hydroxybutyrate & & 1.28 \\
\hline Palmitate & $\mathrm{C}_{16} \mathrm{H}_{32} \mathrm{O}_{2}+7 \mathrm{O}_{2}$ & $\rightarrow 4$ acetoacetate & 1.75 & \\
\hline Palmitate & $\mathrm{C}_{16} \mathrm{H}_{32} \mathrm{O}_{2}+5 \mathrm{O}_{2}$ & $\rightarrow 4 \beta$-hydroxybutyrate & & 1.25 \\
\hline
\end{tabular}

Table 6. Effect of high-fat diet on body weight and ketone-body concentrations in whole blood

The rats were maintained on a high-fat diet containing $90 \%$ margarine (for details see the Materials and Methods section). The values are means \pm s.E.M. and, in parentheses, number of observations.

\begin{tabular}{|c|c|c|c|c|c|c|}
\hline \multirow{3}{*}{$\begin{array}{l}\text { Initial body } \\
\text { weight (g) }\end{array}$} & \multirow{3}{*}{$\begin{array}{l}\text { Days on } \\
\text { high-fat } \\
\text { diet }\end{array}$} & \multirow{3}{*}{$\begin{array}{c}\text { Final body } \\
\text { weight (g) }\end{array}$} & \multirow{2}{*}{\multicolumn{2}{|c|}{ Mean loss of body weight }} & \multicolumn{2}{|c|}{ Ketone bodies in whole blood } \\
\hline & & & & & \multirow{2}{*}{$\begin{array}{l}\text { Total } \\
(\mathrm{mM})\end{array}$} & $\beta$-Hydroxybutyrate \\
\hline & & & Absolute (g) & $\%$ & & Acetoacetate \\
\hline $\begin{array}{l}244 \pm 8(8) \\
245 \pm 10(3)\end{array}$ & $\begin{array}{r}7-12 \\
17-18\end{array}$ & $\begin{array}{l}209 \pm 9(8) \\
208 \pm 8(3)\end{array}$ & $\begin{array}{l}-35 \\
-37\end{array}$ & $\begin{array}{l}14.4 \\
15.1\end{array}$ & $\begin{array}{l}4.32 \pm 0.87(10) \\
5.10 \pm 0.44\end{array}$ & $\begin{array}{r}7.2 \pm 1.8(10) \\
11.5 \pm 3.9\end{array}$ \\
\hline
\end{tabular}

side reaction of no physiological importance. Recently it has been established that $\omega$-oxidation is an extramitochondrial process brought about by the microsomal cytochrome $P-450$ system. Like the hydroxylation of drugs it involves a coupled oxidation with NADPH (Omuro \& Sato, 1964a,b; Orrenius, 1965). The activity of this enzyme system greatly increases on treatment of the animal with various drugs, phenobarbitone being particularly effective (Remmer, 1959).

The $\omega$-oxidation of fatty acids is notable because it could play a role in the formation of carbohydrate from fatty acids, especially during prolonged starvation or on a diet low in carbohydrate and protein. $\omega$-Oxidation of fatty acids with an even number of carbon atoms would lead to the formation of succinyl-CoA, a glucogenic precursor. Thus tri-stearine would yield two molecules of glucose jointly from the glycerol moiety and three terminal carbon atoms of each chain. Without $\omega$-oxidation tri-stearine would give only $0.5 \mathrm{~mol}$ of glucose.

Rats were therefore treated with phenobarbitone to induce a maximum capacity of the microsomal oxidizing system. However, the treatment did not affect the rate of glucose formation, and, as shown in Table 8, the rate of ketone-body formation was the same as without phenobarbitone treatment. Thus even under optimum conditions the fraction of fatty acids undergoing $\omega$-oxidation is negligible.
Question of gluconeogenesis from polyunsaturated fatty acids. Linoleic acid (9,12-octadecadienoic acid), linolenic acid (9,12,15-octadecatrienoic acid) and arachidonic acid $(5,8,11,14$-eicosatetraenoic acid) contain $\mathrm{C}_{3}$ units between double bonds and it has been suggested (Tidwell, Pope \& Gifford, 1966) that these may yield glucose via propionate. Propionate or propionyl-CoA would arise if the degradation of the chain started at the double bonds and if the chain were broken at the site of the double bonds. If this was true arachidonic acid could provide nine out of its 20 carbon atoms for the formation of glucose. The experiment shows that arachidonic acid forms ketone bodies as rapidly as oleate; that the yield of ketone bodies is almost quantitative (Table 9) and that no extra glucose is formed. These results disprove gluconeogenesis from polyunsaturated fatty acids and are in accordance with the conclusions of Stoffel \& Caesar (1965) that the $\beta$-oxidation of polyunsaturated fatty acids yields $\Delta^{\mathbf{2}}$-cis-enoyl-CoA esters which are hydrated by $\Delta^{2}$-enoyl-CoA hydratase to $\mathrm{D}(-)-3$ hydroxyacyl-CoA esters which then epimerize to the $L(+)$-isomeride through the action of 3-hydroxyacyl-CoA epimerase. These reactions channel the whole carbon chain into the pathway of $\beta$-oxidation.

Ketogenesis from other unsaturated and branchedchain fatty acids. Values for the rates of ketogenesis from linoleic acid and oleic acid in the perfused rat liver were reported by Krebs et al. (1969). Values 


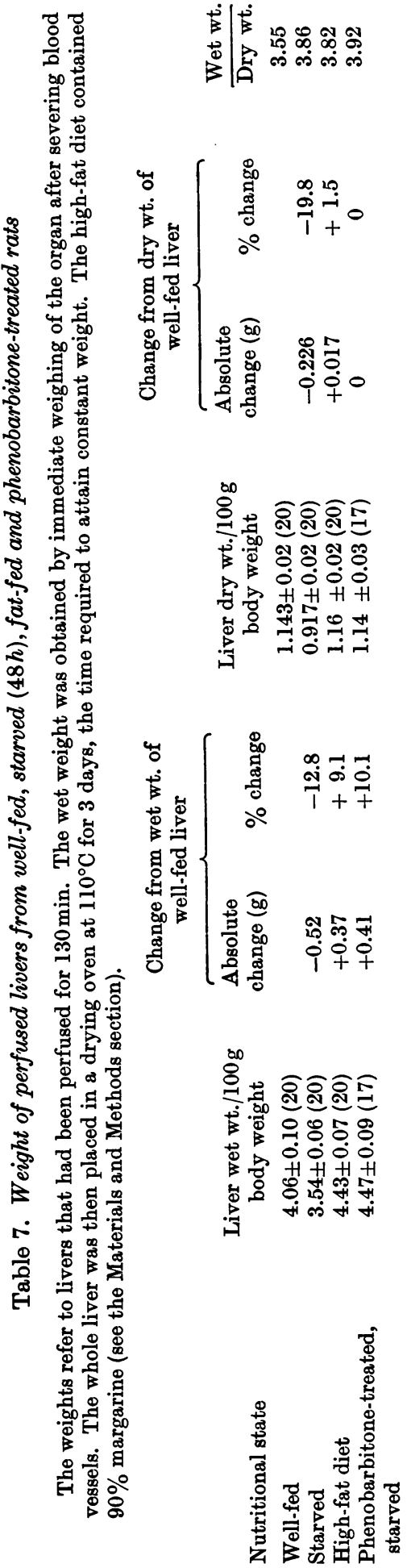

for the rates from sorbate (hexa-2,4-dienoate), undecylenate (hendecenoate), crotonate (but-2-10enoate), vinylacetate (but-3-enoate) and isovalerate (3-methylbutanoate) are given in Table 10. The rates are very similar to those found with the corresponding saturated fatty acids.

Ketone-body formation from substrate combinations. Since short- and long-chain fatty acids are converted into their CoA esters by different enzymes (Leloir \& Muñoz, 1939; Lang, 1939, 1940a,b; Beinert, 1963; Rossi \& Gibson, 1964; Smith \& Osborne-White, 1965; Smith \& Russell, 1967), and since the thiolase reaction as well as the hydrogenation of saturated acyl-CoA esters may also involve different enzymes for short and long chains (see Lynen, 1965), it may be expected that the rates of degradation, as measured by ketone-body formation, are additive when a short- and a longchain fatty acid are added together. The results in Table 11 show that several combinations of oleate with shorter-chain fatty acids gave only slightly higher rates than with oleate alone. The nonadditive behaviour indicates that some enzymes are shared by long- and short-chain fatty acids. According to Lynen (1965) this may be the $\beta$ hydroxyacyl-CoA dehydrogenase and the enoylCoA hydratase (see also Decker, 1959).

Antiketogenic effects. Substances known to be antiketogenic in vivo (glucose, lactate, fructose, xylitol, glycerol, dihydroxyacetone, proline) strongly inhibited endogenous ketogenesis in the starved liver (Table 12), but there were no significant effects when $2 \mathrm{~mm}$-oleate was present in the perfusion medium. These results confirm the view that the relative concentrations of ketogenic and antiketogenic substrates are important factors determining the rate of formation of ketone bodies (Edson, 1936).

Endogenous sources of ketone bodies. The concentration of free fatty acids in the starved rat liver is about $1.3 \mathrm{~mm}$ (Foster, 1967; Falkhoff \& Kipnis, 1966). This amount can supply at most $6 \mu \mathrm{mol}$ of ketone bodies/g fresh weight, as most of the free fatty acids are $\mathrm{C}_{16}$ and $\mathrm{C}_{18}$ acids (Muto \& Gibson, 1970). The rate of endogenous ketogenesis observed in starved-rat liver was $60 \mu \mathrm{mol} / \mathrm{g}$ for the $2 \mathrm{~h}$ period of observation. At this rate the store of free fatty acids would have been exhausted after $5 \mathrm{~min}$. The perfusion medium, made up with albumin as purchased, was found to contain $0.4 \mathrm{~mm}$ free fatty acids as determined by the method of Itaya \& Ui (1965). After defatting of the albumin with charcoal as described by Chen (1967) the free fatty acid content of the medium was $0.04 \mathrm{~mm}$. Defatting did not decrease the rate of 'endogenous' ketogenesis. When this medium was used $7 \mathrm{~g}$ of liver still formed about $420 \mu \mathrm{mol}$ of ketone bodies in $2 \mathrm{~h}$. To this the free fatty acids of the medium could have contri- 
Table 8. Effect of phenobarbitone on the rate of ketone-body formation in the perfused rat liver

The conditions were as described in Table 1, except that the rats had been treated with phenobarbitone as described in the Materials and Methods section. No extra glucose was formed on addition of the fatty acids.

\begin{tabular}{|c|c|c|c|c|}
\hline Substrate added & $\begin{array}{c}\beta-H y d r o x y- \\
\text { butyrate formed } \\
(\mu \mathrm{mol} / \mathrm{h} \text { per } \mathrm{g})\end{array}$ & $\begin{array}{c}\text { Acetoacetate } \\
\text { formed } \\
(\mu \mathrm{mol} / \mathrm{h} \text { per } \mathrm{g})\end{array}$ & $\begin{array}{l}\text { Total ketone } \\
\text { bodies formed } \\
(\mu \mathrm{mol} / \mathrm{h} \text { per } \mathrm{g})\end{array}$ & $\frac{[\beta-\text { Hydroxybutyrate] }}{\text { [Acetoacetate] }}$ \\
\hline None & $6.2 \pm 1.2$ & $20.4 \pm 1.21$ & $26.6 \pm 1.75$ & 0.31 \\
\hline Hexanoate (4 mM) & $43.1 \pm 3.6$ & $95.4 \pm 8.2$ & $138.5 \pm 5.2$ & 0.45 \\
\hline Octanoate (5 mM) & $92 \pm 28$ & $66 \pm 14.9$ & $158 \pm 43.0$ & 1.39 \\
\hline Oleate (2 mM) & $49.4 \pm 5.1$ & $51.8 \pm 8.5$ & $101 \pm 12.9$ & 0.95 \\
\hline
\end{tabular}

\section{Table 9. Formation of ketone bodies and of glucose in perfused rat liver on addition of arachidonate}

The livers were perfused for $90 \mathrm{~min}$ after the addition of arachidonate. The rate of total ketone-body production was constant when the initial substrate concentration was 1 or $2 \mathrm{mM}$. It decreased with $0.5 \mathrm{~mm}$ substrate. The rate given in the latter case is the initial rate. The [ $\beta$-hydroxybutyrate]/[acetoacetate] ratio was about 1 initially and fell to 0.5 . The liver weights were between 5.1 and $7.4 \mathrm{~g}$. The rate of glucose formation in controls without added substrate was up to $70 \mu \mathrm{mol} / 90 \mathrm{~min}$ per liver.

\begin{tabular}{|c|c|c|c|c|c|c|}
\hline $\begin{array}{c}\text { Treatment } \\
\text { of rat }\end{array}$ & $\begin{array}{l}\text { Arachidonate } \\
\text { added }\end{array}$ & $\begin{array}{c}\text { Rate of ketone- } \\
\text { body } \\
\text { formation } \\
(\mu \mathrm{mol} / \mathrm{h} \text { per } \mathrm{g})\end{array}$ & $\begin{array}{l}\text { Total ketone } \\
\text { bodies } \\
\text { formed } \\
(\mu \mathrm{mol})\end{array}$ & $\begin{array}{l}\text { Theoretical } \\
\text { ketone-body } \\
\text { yield from } \\
\text { added substrate } \\
(\mu \mathrm{mol})\end{array}$ & $\begin{array}{c}\text { Rate of } \\
\text { glucose } \\
\text { formation } \\
(\mu \mathrm{mol} / \mathrm{h} \text { per } \mathrm{g})\end{array}$ & $\begin{array}{l}\text { Total glucose } \\
\text { formed } \\
(\mu \mathrm{mol})\end{array}$ \\
\hline Starved $(48 \mathrm{~h})$ & $2 \mathrm{mM}(300 \mu \mathrm{mol})$ & 73.6 & 565 & 1500 & 4.4 & 34 \\
\hline Starved $(48 \mathrm{~h})$ & $2 \mathrm{~mm}(300 \mu \mathrm{mol})$ & 71.6 & 649 & 1500 & 2.7 & 25 \\
\hline Starved $(48 \mathrm{~h})$ & $1 \mathrm{mM}(150 \mu \mathrm{mol})$ & 79.5 & 705 & 750 & 5.7 & 59 \\
\hline Starved $(48 \mathrm{~h})$ & $1 \mathrm{~mm}(150 \mu \mathrm{mol})$ & 99.6 & 765 & 750 & 4.0 & 35 \\
\hline Starved (48h) & $0.5 \mathrm{~mm}(75 \mu \mathrm{mol})$ & 63.1 & 420 & 375 & 5.3 & 58 \\
\hline Starved (48h) & $0.5 \mathrm{mM}(75 \mu \mathrm{mol})$ & 43.0 & 382 & 375 & 8.0 & 71 \\
\hline High-fat diet & $2 \mathrm{mM}(300 \mu \mathrm{mol})$ & 71.8 & 761 & 1500 & 4.8 & 43 \\
\hline High-fat diet & $2 \mathrm{mM}(300 \mu \mathrm{mol})$ & 86.7 & 668 & 1500 & 2.1 & 23 \\
\hline
\end{tabular}

Table 10. Ketone-body formation from unsaturated and branched-chain fatty acids

The experimental conditions were as described in Table 1 . The values are means \pm S.E.M., with numbers of observations in parentheses.

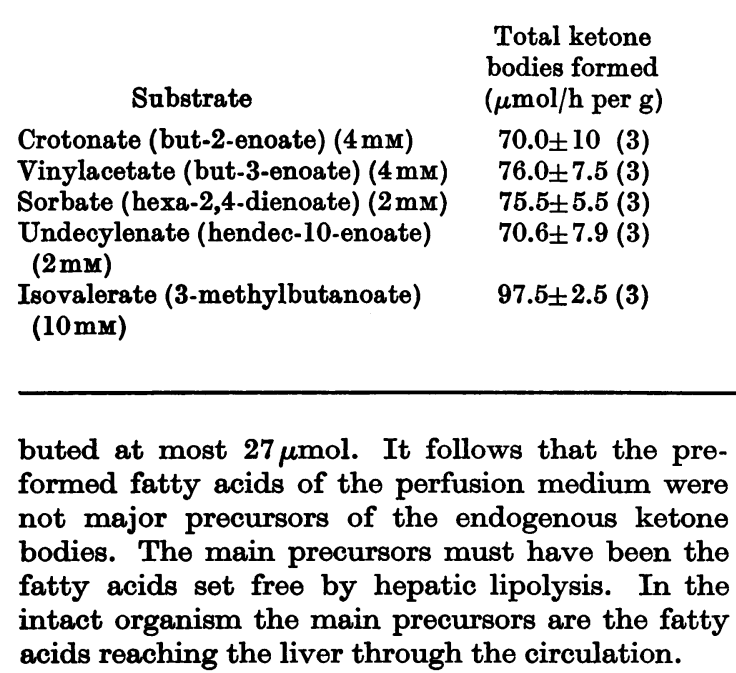

[ $\beta$-Hydroxybutyrate]/[acetoacetate] ratio in medium after addition of substrate

\begin{tabular}{lcc}
\hline $30 \min$ & $60 \min$ & $90 \min$ \\
$0.22 \pm 0.6$ & $0.14 \pm 0.04$ & $0.11 \pm 0.03$ \\
$0.44 \pm 0.04$ & $0.32 \pm 0.02$ & $0.24 \pm 0.01$ \\
$0.42 \pm 0.12$ & $0.28 \pm 0.11$ & $0.21 \pm 0.04$ \\
$1.51 \pm 0.66$ & $1.00 \pm 0.32$ & $0.69 \pm 0.30$ \\
$0.28 \pm 0.07$ & $0.30 \pm 0.16$ & $0.29 \pm 0.11$
\end{tabular}

\section{DISCUSSION}

Rates of ketogenesis from fatty acids. Qualitatively ketogenesis from the precursors tested in this work was already known (for review see Deuel, 1957), but quantitative information on the ketogenic capacity was not available before the use of the 
isolated perfused rat liver. Compared with slices the rates of ketogenesis in the perfused organ are very high. With long-chain fatty acids the rate is more than ten times as fast in the intact organ at the same substrate concentration (Krebs, 1967).

One of the most drastic changes that occurs on slicing, and occurs with great rapidity, is the decrease in the ATP concentration and the loss of total adenine nucleotides (see Krebs, 1970). It is likely that this is one of the factors responsible for the different behaviour of slices and perfused organs. It might be expected that all energyrequiring reactions are equally affected by the loss of ATP, but this is not the case. It appears that the rate of urea synthesis can be high even if much ATP has been lost.

Effect of diet on the rate of ketone-body formation. Maximal rates of hepatic ketogenesis were obtained on rats given a diet containing $90 \%(w / w)$ fat. With $2 \mathrm{~mm}$-oleate in the perfusion medium the rates

\section{Table 11. Rates of ketone-body formation on addition of two substrates}

The experimental conditions were as described in Table 1. For the values of the rates with sorbate alone see Table 10, and of the rates for the other substances see Table 1.

Substrates added
Oleate $(2 \mathrm{~mm})$
Oleate $(2 \mathrm{mM})+$ butyrate $(10 \mathrm{~mm})$
Oleate $(2 \mathrm{mM})+$ heptanoate
(2 mM, added twice)
Oleate (2 mM)+dodecanoate
$(2.5 \mathrm{mM})$
Oleate $(2 \mathrm{mM})+$ sorbate $(2 \mathrm{mM})$

Rate of total ketonebody formation ( $\mu \mathrm{mol} / \mathrm{h}$ per $\mathrm{g}$ )

$98.4 \pm 4.7(4)$

$110 \pm 7.5(4)$

$100 \pm 9.5(2)$

$122 \pm 1.0(2)$

$111 \pm 7.5(4)$ were about $30 \%$ higher than those of starved rats, and $300 \%$ higher than those of rats fed on a standard diet. The endogenous rate of ketogenesis was also raised by about $30 \%$ (Table 3). One of the factors responsible for the high rate of ketogenesis on fat feeding is probably the increased capacity of hydroxymethylglutaryl-CoA synthase, the ratelimiting enzyme of ketogenesis. The capacity of this enzyme is known to increase by $140 \%$ on fat feeding (Williamson, Bates \& Krebs, 1968). Stadie (1940) and Stadie, Zapp \& Lukens (1940, 1941) found that in severe diabetic ketosis most of the $\mathrm{O}_{2}$ consumption of rat or cat liver was used for the conversion of fatty acids into ketone bodies, as indicated by a very low respiratory quotient $(0.32)$. This change of liver metabolism towards the generation of ketone bodies is even more pronounced in the livers of fat-fed rats. The significance of hepatic ketogenesis lies in the supply of a fuel of respiration to peripheral tissues (Krebs, 1961; Cahill et al. 1968; Owen et al. 1967) and it follows from the results given in Table 4 that virtually the whole of the respiration is concerned with this function when fat is the predominant fuel of respiration of the organism. The high rates of ketogenesis, it is true, occurred on addition of oleate to the perfusion medium, but the concentrations used (2mm initially) are near the physiological range in animals depending on fat as energy source. At a rate of ketone-body production of $2.7 \mu \mathrm{mol} / \mathrm{min}$ per $\mathrm{g}$ (Table 4 ) the daily ketone-body production would be about $3 \mathrm{~g}$ for a rat weighing $200 \mathrm{~g}$. A rat of this size consumes, under normal conditions, about $14 \mathrm{~g}$ (dry weight) of rat cubes daily. Thus maximally about $20 \%$ of the calorie needs could be provided by the ketone bodies generated in the liver.

Mechanism of antiketogenesis. The fact that the

\section{Table 12. Antiketogenic effects in the perfused rat liver}

The rats were starved for $48 \mathrm{~h}$. The initial concentration of the antiketogenic agent was $10 \mathrm{~mm}$. The values are means \pm S.E.M. with numbers of observations in parentheses.

\begin{tabular}{|c|c|c|c|c|}
\hline Antiketogenic substrate & $\begin{array}{l}\text { Rate of endogenous } \\
\text { total ketone-body } \\
\text { formation } \\
(\mu \mathrm{mol} / \mathrm{h} \text { per } \mathrm{g})\end{array}$ & $\begin{array}{c}\text { Inhibition of } \\
\text { endogenous } \\
\text { ketogenesis } \\
(\%)\end{array}$ & $\begin{array}{l}\text { Rate of total } \\
\text { ketone-body } \\
\text { formation in the } \\
\text { presence of } \\
2 \mathrm{~mm} \text {-oleate } \\
\text { ( } \mu \mathrm{mol} / \mathrm{h} \text { per } \mathrm{g})\end{array}$ & $\begin{array}{c}\text { Inhibition of } \\
\text { ketogenesis } \\
\text { from oleate } \\
(\%)\end{array}$ \\
\hline None & $30.4 \pm 3.3(4)$ & & $98 \pm 4.7(4)$ & \\
\hline L-Lactate & $6.5 \pm 0.29(3)$ & 79 & $85 \pm 5.4(6)$ & 13 \\
\hline Glucose & $11.5 \pm 2.9(3)$ & 62 & & \\
\hline Fructose & $9.7 \pm 0.9(4)$ & 68 & & \\
\hline Xylitol & $12.2 \pm 3.3(4)$ & 60 & $101 \pm 12.4(3)$ & $\mathbf{0}$ \\
\hline Glycerol & $10.5 \pm 1.6(4)$ & 65 & $90 \pm 8.8(4)$ & 8 \\
\hline Dihydroxyacetone & $15.0 \pm 3.0(3)$ & 51 & & \\
\hline Proline & $13.3 \pm 3.8(3)$ & 56 & & \\
\hline
\end{tabular}


rate of ketogenesis from fatty acids increases with the substrate concentration (see Heimberg, Weinstein \& Kohout, 1969; Van Harken, Dixon \& Heimberg, 1969; Krebs et al. 1969) and that the antiketogenic effects of carbohydrates, carbohydrate derivatives and amino acids (Table 12) depend on the concentration of ketogenic precursors implies that the regulation of ketogenesis is related to the regulation of the tissue concentration of free fatty acids, the main ketogenic precursors. This concentration in turn depends mainly on the rate at which fatty acids reach the liver from the triglyceride stores of adipose tissue and from the intestine.

Effect of long-chain fatty acids on the [ $\beta$-hydroxybutyrate]/[acetoacetate] ratio. A striking effect of long-chain fatty acids is a rise of the [ $\beta$-hydroxybutyrate]/[acetoacetate] ratio, or the maintenance of a high ratio, in the perfusion medium (Tables 1 and 3; see also Williamson, Browning \& Scholz, 1969). The ratios found after addition of long-chain fatty acids to the medium are those found in vivo in liver and in blood plasma, and it appears that long-chain fatty acids are the only physiological substrates that maintain a high ratio in the perfused organ. As the ratio is indicative of the mitochondrial redox state it follows that the long-chain fatty acids play a role in the control of the mitochondrial redox state in the liver.

This work was supported by the Medical Research Council and by U.S. Public Health Service Grant no. AM 11748-01.

\section{REFERENCES}

Beinert, H. (1963). In The Enzymes, vol. 7, p. 467. Ed. by Boyer, P. B., Lardy, H. \& Myrbäck, K. New York and London: Academic Press.

Bernhard, K. (1941). Helv. Chim. Acta, 24, 1412.

Cahill, G. F., jun., Owen, O. E. \& Morgan, A. P. (1968). In Advances in Enzyme Regulation, vol. 6, p. 143. Ed. by Weber, G. Oxford and New York: Pergamon Press. Chen, R. F. (1967). J. biol. Chem. 242, 173.

Das, M. L., Orrenius, S. \& Ernster, L. (1968). Eur. J. Biochem. 4, 519.

Decker, K. (1959). Die aktivierte Essigsäure, p. 53. Stuttgart: Ferd. Enke.

Deuel, H. J., jun. (1957). The Lipids, vol. 3, especially p. $71 \mathrm{ff}$. New York: Interscience Publishers Inc.

Edson, N. L. (1936). Biochem. J. 30, 1862.

Falkhoff, R. K. \& Kipnis, D. M. (1966). Diabetes, 15, 443.

Foster, D. W. (1967). J. clin. Invest. 46, 1283.

Heimberg, M., Weinstein, I. \& Kohout, M. (1969). J. biol. Chem. 244, 5131.
Itaya, K. \& Ui, M. (1965). J. Lipid Res. 6, 16.

Krebs, H. A. (1961). Biochem. J. 80, 225.

Krebs, H. A. (1967). 3. Konf. Ges. Biol. Chemie, p. 129. Berlin, Heidelberg and New York: Springer-Verlag.

Krebs, H. A. (1970). In Advances in Enzyme Regulation, vol. 8, p. 335. Ed. by Weber, G. Oxford and New York: Pergamon Press.

Krebs, H. A., Wallace, P. G., Hems, R. \& Freedland, R. A. (1969). Biochem. J. 112, 149.

Lang, K. (1939). Hoppe-Seyler's Z. physiol. Chem. 261, 240.

Lang, K. (1940a). Hoppe-Seyler's Z. physiol. Chem. 262, 123.

Lang, K. (1940b). Hoppe-Seyler's Z. physiol. Chem. 262, 249.

Leloir, L. F. \& Muñoz, J. M. (1939). Biochem. J. 33, 734.

Lynen, F. (1965). Angew. Chem. 77, 929.

Muto, Y. \& Gibson, D. M. (1970). Biochem. biophys. Res. Commun. 38, 9.

Omuro, T. \& Sato, R. (1964a). J. biol. Chem. 239, 2370.

Omuro, T. \& Sato, R. (1964b). J. biol. Chem. 239, 2379.

Orrenius, S. (1965). J. Cell Biol. 26, 713.

Osbond, J. M. (1966). In Progress in the Chemistry of Fats and other Lipids, vol. 9, p. 119. Ed. by Holman, R. T. Oxford and New York: Pergamon Press.

Owen, O. E., Morgan, A. P., Kemp, H. G., Sullivan, J. M., Herrera, M. G. \& Cahill, G. F. (1967). J. clin. Invest. 46, 1589.

Remmer, H. (1959). Arch. exp. Path. Pharmak. 237, 296.

Remmer, H., Greim, H., Schenkman, J. B. \& Estabrook, R. W. (1967). In Methods in Enzymology, vol. 10, p. 109. Ed. by Estabrook, R. W. \& Pullman, M. E. New York: Academic Press Inc.

Rossi, C. R. \& Gibson, D. M. (1964). J. biol. Chem. 239, 1694.

Smith, R. M. \& Osborne-White, W. S. (1965). Biochem. J. 95, 411.

Smith, R. M. \& Russell, G. R. (1967). Biochem. J. 102, 390.

Stadie, W. C. (1940). J. clin. Invest. 19, 843.

Stadie, W. C., Zapp, J. A., jun. \& Lukens, F. D. W. (1940). J. biol. Chem. 132, 423.

Stadie, W. C., Zapp, J. A., jun. \& Lukens, F. D. W. (1941). J. biol. Chem. 137, 75.

Stoffel, W. \& Caesar, H. (1965). Hoppe-Seyler's Z. physiol. Chem. 341, 76.

Tidwell, H. C., Pope, J. L. \& Gifford, P. (1966). J. Nutr. 88, 11.

Van Harken, D. R., Dixon, C. W. \& Heimberg, M. (1969). J. biol. Chem. 244, 2278.

Verkade, P. E. \& van der Lee, J. (1934). Biochem. J. 28, 31 .

Verkade, P. E., van der Lee, J. \& van Alphen, A. J. S. (1938). Hoppe-Seyler's Z. physiol. Chem. 252, 163.

Williamson, D. H., Bates, M. W. \& Krebs, H. A. (1968). Biochem. J. 108, 353.

Williamson, J. R., Browning, E. T. \& Scholz, R. (1969). J. biol. Chem. 244, 4607. 